\title{
Influence of the fetal pituitary-adrenal axis on fetal and maternal progesterone and unconjugated oestrogen concentrations in the pig
}

\author{
G. C. B. Randall and *B. K. Tsang \\ Agriculture Canada, Animal Diseases Research Institute, NEPEAN, P.O. Box 11300, Station H, \\ Nepean, Ontario, Canada K2H $8 P 9$ and ${ }^{*}$ Reproductive Biology Unit, Departments of Obstetrics \& \\ Gynaecology, and Physiology, University of Ottawa, Ottawa Civic Hospital, Ottawa, Ontario, \\ Canada K1Y $4 E 9$
}

\begin{abstract}
Summary. Fetal and maternal plasma progesterone and unconjugated oestrone and oestradiol-17 $\beta$ concentrations were measured in intact pig fetuses and those in which the pituitary had been destroyed. Progesterone concentrations were significantly higher $(P<0.05)$ and oestrogen concentrations significantly lower $(P<0.01)$ in hypophysectomized fetuses than in intact fetuses. When fetuses in one uterine horn only were hypophysectomized, oestrogen concentrations in the uterine vein draining this horn were lower than those from the contralateral vein. The results indicate that both fetal and maternal oestrogen concentrations are influenced by the fetal pituitary. When dexamethasone was infused (at $27 \mu \mathrm{g} / \mathrm{h}$ for $96 \mathrm{~h}$ ) into 5 chronically-catheterized hypophysectomized fetuses no changes in peripheral fetal progesterone or oestrone were observed.
\end{abstract}

\section{Introduction}

Fetal progesterone concentrations in the pig are considerably higher than maternal concentrations during late pregnancy (Barnes, Comline \& Silver, 1974; Silver et al., 1979; Hagen, Houtz, Griel \& Kavanaugh, 1983) although they appear to decrease during the last week of gestation (Silver et al., 1979; Macdonald et al., 1979). The major sources of fetal progesterone are the placenta (Silver et al., 1979; Craig, 1982) or active transfer from the maternal circulation (Barnes et al., 1974), whereas little is produced by the fetal adrenal during late gestation (Macdonald, Colenbrander, Elsaesser \& Heilhecker, 1980).

Oestrogen concentrations increase in the maternal (Robertson \& King, 1974) and fetal (Macdonald et al., 1979) circulations during the last month of gestation, with a more rapid increase occurring in the last week. Maternal oestradiol-17 $\beta$ concentrations have been shown to be lower in gilts carrying small numbers of hypophysectomized fetuses than in those carrying small numbers of normal fetuses (Kendall, Dziuk, Nelson \& Thurmon, 1985). The placenta is the major source of oestrogens during gestation in the pig (Fèvre, Léglise \& Rombauts, 1968; Robertson \& King, 1974) and Craig (1982) showed that the placenta has limited enzymic ability to synthesize oestrogens from pregnenolone by the $\Delta^{4}$-pathway in vitro. Moreover, the activity of those enzymes essential for the metabolism of progesterone to oestrone increased at term. Activation of one of these enzymes, 17 $\alpha$-hydroxylase, is mediated by fetal cortisol in sheep and goats (Anderson, Flint \& Turnbull, 1975; Flint, Kingston, Robinson \& Thorburn, 1978) and forms part of the cascade by which parturition is induced by the fetal pituitary-adrenal axis. A similar mechanism has been suggested for the pig (Craig, 1982). Fetal decapitation (Stryker \& Dziuk, 1975) or hypophysectomy (Bosc, du Mesnil du Buisson \& Locatelli, 1974) are known to prolong gestation in the pig and 
during the development of these procedures we found that progesterone concentrations were higher in hypophysectomized than in intact fetuses. The present study was carried out to determine whether the fetal pituitary influenced progesterone and unconjugated oestrogen concentrations in fetal plasma and whether this might be mediated through glucocorticosteroids.

\section{Materials and Methods}

Surgical procedures. Yorkshire gilts weighing $92-164 \mathrm{~kg}$ were used; pre- and post-operative handling and anaesthetic regimens have been described previously (Randall, 1977). All surgical procedures were performed under general anaesthesia. The study was carried out in three experiments.

Experiment 1 . In this experiment, all fetuses in a litter were decapitated or hypophysectomy was attempted on all fetuses in the litter. Decapitation was performed between Days 40 and 45 (Stryker \& Dziuk, 1975) and hypophysectomy between Days 74 and 84 of gestation as described in detail elsewhere (Randall, 1986). Briefly, the pituitary was destroyed by electrocoagulation following blind passage of a probe through the uterine wall and fetal skull to the sella turcica. Pregnancy was then allowed to continue until 119-122 days of gestation when the fetuses were removed at Caesarian section and blood samples were collected from the umbilical artery and vein. Similar samples were collected at 112 and 114 days of gestation from unoperated fetuses (intact) in 2 gilts. Samples from 8 fetuses ( 4 male; 4 female) were assayed in each group. These were selected randomly from 3 'decapitated', 4 'hypophysectomized' and the 2 intact litters.

Experiment 2. Since fetal hypophysectomy resulted in prolonged gestation and differences in gestational ages between groups in Exp. 1, a second experiment was designed to compare fetuses at the same gestational age and within the same litter. In 4 gilts all the fetuses in one uterine horn were hypophysectomized whereas those in the other horn were left intact. At a second operation (Days 103-105 of gestation) polyvinyl catheters were inserted into branches of the uterine vein of each horn and the middle uterine artery in one horn (Randall, 1977). To remove the contribution of maternal progesterone, one of these gilts was bilaterally ovariectomized when the catheters were inserted, and pregnancy was maintained by feeding medroxyprogesterone acetate ( $100 \mathrm{mg} / \mathrm{day}$ : Sigma Chemical Co., St Louis, MO, U.S.A.). Maternal blood samples were collected from each vessel until Day 112-113 of gestation when Caeasarian section was performed and samples collected as in Exp. 1. The completeness of the hypophysectomy was assessed by gross examination of the pituitary fossa for pituitary remnants and by determining fetal cortisol concentrations in arterial plasma. This assessment was subsequently confirmed by determination of plasma $\mathrm{LH}$ concentrations (Ponzilius, Sanford, Phillips \& Palmer, 1983).

Experiment 3. In 3 gilts, fetuses in one uterine horn were hypophysectomized on Days 70,73 and 76 of gestation. On Day 105 of gestation two polyvinyl catheters were inserted into the jugular veins (or into one vein and a carotid artery) of 1 or 2 hypophysectomized fetuses in each gilt by previously described techniques (Randall, 1986). At this time, the gilts were bilaterally ovariectomized and pregnancy was maintained as in Exp. 2. Fetal blood samples $(1.5 \mathrm{ml})$ were collected daily from the fetal jugular catheter until Caesarian section. Beginning 2-5 days after fetal catheterization, all 5 fetuses were infused continuously through the other catheter with dexamethasone (Dexagen, Rogar/STB, Pointe Claire, Quebec) at a rate of $27 \mu \mathrm{g} / \mathrm{h}$. This rate was approximately $25 \%$ higher than that shown to suppress endogenous cortisol production in intact fetuses (Randall, Kendall, Tsang \& Taverne, 1984). The infusion was continued for $96 \mathrm{~h}$ and the total volume infused per day was $\sim 3.0 \mathrm{ml}$. The gilts were then anaesthetized and fetal blood samples were collected as before.

In all experiments, blood samples were collected into pre-chilled tubes containing EDTA (Vacutainers, Becton-Dickinson Canada, Mississauga, Ontario) and immediately centrifuged at $4^{\circ} \mathrm{C}$. The separated plasma was stored at $-20^{\circ} \mathrm{C}$ until assayed. 
Hormone assays. Progesterone was estimated in duplicate by radioimmunoassay (RIA) by procedures described previously (Randall, Taverne, Challis, Kendall \& Tsang, 1986). Plasma volumes of 25 and $50 \mu \mathrm{l}$ were used for fetal and 100 and $200 \mu \mathrm{l}$ for maternal determinations. The intra- and inter-assay coefficients of variation were $6.8 \%$ and $17 \cdot 2 \%$ respectively. In 5 fetal samples, progesterone was estimated with and without prior LH-20 chromatography (Murphy, 1971) and concentrations in both were in close agreement. Unconjugated oestrone and oestradiol-17 $\beta$ concentrations were estimated using RIA procedures previously described (Tsang, Armstrong \& Whitfield, 1980). Combined intra- and inter-assay coefficients of variation were $<10 \%$ for oestrone and $<15 \%$ for oestradiol- $17 \beta$. Cortisol was estimated by RIA using an antibody produced in a rabbit against cortisol 3-CMO-BSA. The main cross-reacting steroids were cortisone $(4 \cdot 4 \%)$, corticosterone $(2 \cdot 2 \%), 17$-hydroxyprogesterone $(2 \cdot 2 \%)$ and 11 -desoxycortisol $(2 \cdot 2 \%)$. All other steroids tested cross-reacted at $<0 \cdot 2 \%$. Plasma samples $(10$ or $20 \mu \mathrm{l})$ were diluted to $0 \cdot 22 \mathrm{ml}$ with distilled water, prewashed twice with $2 \mathrm{ml}$ hexane-carbon tetrachloride $(1 \cdot 5: 1, \mathrm{v} / \mathrm{v})$ to remove progesterone and extracted twice with redistilled dichloromethane $(1.0 \mathrm{ml})$. Combined organic extracts were evaporated to dryness and reconstituted (as were standards) in $0.5 \mathrm{ml} 0.1 \mathrm{M}$-phosphate buffer, pH 7.0, containing $0 \cdot 1 \%$ gelatin. To each tube, $100 \mu$ of a 1:3000 dilution of antibody were added and the tubes were incubated at room temperature for $30 \mathrm{~min}$ after which time $100 \mu \mathrm{l}\left[{ }^{3} \mathrm{H}\right]$ cortisol trace solution were added. The tubes were then vortexed and incubated overnight at $4^{\circ} \mathrm{C}$. Bound and free steroids were separated by adding $300 \mu \mathrm{l}$ of the buffer containing $0.5 \%$ charcoal and $0.05 \%$ Dextran T-70, vortexing and centrifuging the mixture at $4{ }^{\circ} \mathrm{C} ; 500 \mu \mathrm{l}$ were then removed for scintillation counting. The average recovery of $\left[{ }^{3} \mathrm{H}\right]$ cortisol added to three aliquants of plasma in each assay was $80.4 \%$ and results were corrected for extraction losses. When cortisol was added to pig plasma (previously stripped of endogenous steroids with charcoal) to provide concentrations of $0,20,50$ and $100 \mathrm{ng} / \mathrm{ml}, 10 \mu \mathrm{l}$ samples handled as above yielded $0 \cdot 46,20 \cdot 3,52 \cdot 6$ and $108 \cdot 4 \mathrm{ng} / \mathrm{ml}$ $(n=11)$. Intra- and inter-assay coefficients of variation were $8.2 \%$ and $7 \cdot 5 \%$ respectively.

The significance of differences between concentrations of steroids in different groups was assessed by one-way analysis of variance using the Newman-Keuls procedure to identify significant differences or by Student's $t$ test when appropriate.

\section{Results}

\section{Experiment 1}

Gestation was prolonged in all gilts carrying decapitated or hypophysectomized fetuses. Progesterone concentrations were significantly higher and oestrogen significantly lower in decapitated or hypophysectomized fetuses than in intact fetuses (Table 1). Individual values for both progesterone and oestrone, however, varied considerably within groups although there were no consistent differences between males and females. There was a negative arterio-venous difference for all three steroids $(P<0.05)$ in all fetal groups. Mean fetal cortisol concentrations were $6 \cdot 7$, 8.9 , and $47.3 \mathrm{ng} / \mathrm{ml}$ for decapitated, hypophysectomized and intact fetuses respectively.

\section{Experiment 2}

In 1 of the 13 hypophysectomized fetuses small remnants of pituitary tissue remained and this fetus had an $\mathrm{LH}$ concentration of $0.78 \mathrm{ng} / \mathrm{ml}$. Concentrations of progesterone and oestrone in the umbilical artery and vein were 40.3 and $78.1 \mathrm{ng} / \mathrm{ml}$ and 2122 and $3412 \mathrm{pg} / \mathrm{ml}$ respectively. In one other fetus the pituitary was missed, a small lesion being present on the latero-ventral surface of the left cerebral hemisphere, and data from this fetus are included in the 'intact' group. In all other hypophysectomized fetuses LH concentrations were below assay sensitivity $(0 \cdot 13 \mathrm{ng} / \mathrm{ml})$. As in Exp. 1, oestrone and progesterone concentrations in hypophysectomized fetuses were significantly 
Table 1. Mean concentrations ( \pm s.e.m.) of progesterone, unconjugated oestrone and oestradiol-17 in the umbilical blood of pig fetuses at Caesarian section

\begin{tabular}{|c|c|c|c|c|c|c|c|}
\hline \multirow[b]{2}{*}{ Group } & \multirow{2}{*}{$\begin{array}{l}\text { Gestational } \\
\text { age (days) }\end{array}$} & \multicolumn{2}{|c|}{$\begin{array}{l}\text { Progesterone } \\
\quad(\mathrm{ng} / \mathrm{ml})\end{array}$} & \multicolumn{2}{|c|}{$\begin{array}{l}\text { Oestrone } \\
(\mathrm{pg} / \mathrm{ml})\end{array}$} & \multicolumn{2}{|c|}{$\begin{array}{l}\text { Oestradiol-17ß } \\
\quad(\mathrm{pg} / \mathrm{ml})\end{array}$} \\
\hline & & Artery & Vein & Artery & Vein & Artery & Vein \\
\hline $\begin{array}{l}\text { Decapitated } \\
\quad(n=8)\end{array}$ & $119-122$ & $\begin{array}{r}* 31 \cdot 2 \\
\pm 7 \cdot 4\end{array}$ & $\begin{array}{r}* * 77.6 \\
\pm \quad 9.2\end{array}$ & $\begin{array}{l}* * 995.5 \\
\pm 169.9\end{array}$ & $\begin{array}{l}* * 1956.6 \\
\pm \quad 416.0\end{array}$ & $\begin{array}{l}* * 151 \\
\pm 10.8\end{array}$ & $\begin{array}{l}* * 195 \\
\pm 15 \cdot 3\end{array}$ \\
\hline $\begin{array}{l}\text { Hypophysectomized } \\
\quad(n=8)\end{array}$ & $119-120$ & $\begin{array}{r}* 33.8 \\
\pm 5.4\end{array}$ & $\begin{array}{l}* * 76.5 \\
\pm 16.9\end{array}$ & $\begin{array}{l}* * 847.9 \\
\pm 181.9\end{array}$ & $\begin{array}{r}* * 1953 \cdot 4 \\
\pm \quad 377.6\end{array}$ & $\begin{array}{l}* * 127 \\
\pm 11 \cdot 1\end{array}$ & $\begin{array}{l}* * 165 \\
\pm \quad 3.5\end{array}$ \\
\hline $\begin{array}{l}\text { Intact } \\
\qquad(n=8)\end{array}$ & $112-114$ & $\begin{array}{r}10.0 \\
\pm 1.4\end{array}$ & $\begin{array}{r}25 \cdot 5 \\
\pm \quad 2.5\end{array}$ & $\begin{array}{r}2699 \cdot 5 \\
\pm 284 \cdot 0\end{array}$ & $\begin{array}{r}8552 \cdot 0 \\
\pm 1412 \cdot 0\end{array}$ & $\begin{array}{l}250 \\
\pm 17 \cdot 3\end{array}$ & $\begin{array}{c}431 \\
\pm 18 \cdot 7\end{array}$ \\
\hline
\end{tabular}

$n=$ number of fetuses in group.

Values significantly different from those of intact fetuses: ${ }^{*} P<0 \cdot 05 ; * * P<0.01$.

Table 2. Mean concentrations ( \pm s.e.m.) of progesterone, unconjugated oestrone and oestradiol-17 $\beta$ in the umbilical blood of hypophysectomized pig fetuses and their intact litter mates

\begin{tabular}{|c|c|c|c|c|c|c|}
\hline \multirow[b]{2}{*}{ Group } & \multicolumn{2}{|c|}{$\begin{array}{l}\text { Progesterone } \\
(\mathrm{ng} / \mathrm{ml})\end{array}$} & \multicolumn{2}{|c|}{$\begin{array}{l}\text { Oestrone } \\
(\mathrm{pg} / \mathrm{ml})\end{array}$} & \multicolumn{2}{|c|}{$\begin{array}{l}\text { Oestradiol-17 } \beta \\
(\mathrm{pg} / \mathrm{ml})\end{array}$} \\
\hline & Artery & Vein & Artery & Vein & Artery & Vein \\
\hline $\begin{array}{l}\text { Hypophysectomized } \\
\quad(n=12)\end{array}$ & $\begin{array}{r}* * 22 \cdot 6 \\
\pm 2 \cdot 3\end{array}$ & $\begin{array}{r}* * 55 \cdot 0 \\
\pm 4.5\end{array}$ & $\begin{array}{r}* 1786 \cdot 4 \\
\pm 190 \cdot 6\end{array}$ & $\begin{array}{r}* * 3745 \cdot 6 \\
\pm 519 \cdot 2\end{array}$ & $\begin{array}{r}134 \cdot 1 \\
+\quad 9 \cdot 2\end{array}$ & $\begin{array}{l}* 167 \cdot 1 \\
\pm 13.3\end{array}$ \\
\hline $\begin{array}{l}\text { Intact } \\
\qquad(n=13)\end{array}$ & $\begin{array}{r}13 \cdot 3 \\
+1.82\end{array}$ & $\begin{array}{r}30 \cdot 2 \\
\pm 2.8\end{array}$ & $\begin{array}{r}3418.7 \\
+624.9\end{array}$ & $\begin{array}{r}7627 \cdot 4 \\
\pm 927 \cdot 1\end{array}$ & $\begin{array}{r}168 \cdot 2 \\
\pm 19 \cdot 5\end{array}$ & $\begin{array}{r}234 \cdot 4 \\
\pm 20 \cdot 3\end{array}$ \\
\hline
\end{tabular}

$n=$ number of fetuses in group.

Values significantly different from those of intact fetuses: ${ }^{*} P<0.025 ;{ }^{* *} P<0.005$.

Table 3. Individual maternal unconjugated oestrogen concentrations (pg/ml) at Caesarian section in sows in which fetuses in one uterine horn were hypophysectomized

\begin{tabular}{lccc}
\hline & \multicolumn{2}{c}{ Maternal uterine vein } \\
\cline { 2 - 4 } & $\begin{array}{c}\text { Maternal uterine } \\
\text { artery }\end{array}$ & $\begin{array}{c}\text { Intact } \\
\text { fetuses* }\end{array}$ & $\begin{array}{c}\text { Hypophysectomized } \\
\text { fetuses }{ }^{*}\end{array}$ \\
\hline Oestrone & 1960 & $3359(6)$ & $2503(5 / 5)$ \\
& 2603 & $5106(2)$ & $2638(4 / 4)$ \\
Oestradiol-17ß & - & $10611(5)$ & $6214(4 / 5)$ \\
& $1047 \ddagger$ & $5524(1)$ & $3431(3 / 3)$ \\
& 170 & 191 & 164 \\
& 160 & 191 & 169 \\
& $141 \ddagger$ & 276 & 198 \\
\hline
\end{tabular}

*Number of fetuses in parentheses.

$\dagger$ Number of fetuses successfully hypophysectomized in horn in parentheses.

†Ovariectomized sow. 
different from those of their intact littermates (Table 2) and these differences were more marked in the umbilical vein. Differences between arterial oestradiol-17 $\beta$ concentrations were not significant although those in the umbilical vein were. Marked variations in the steroid concentrations of individual fetuses were present and this was more marked in the intact fetuses. Mean fetal arterial cortisol concentrations were 5.7 and $42.6 \mathrm{ng} / \mathrm{ml}$ for hypophysectomized and intact fetuses respectively.

In all 4 sows, unconjugated oestrone and oestradiol-17 $\beta$ concentrations were higher in the uterine vein draining the horn containing intact fetuses than in that draining the horn containing hypophysectomized fetuses (Table 3). However, concentrations in both veins were generally higher than those in the uterine artery.

\section{Experiment 3}

Fetal packed cell volumes were unchanged during the experimental period and, when measured, fetal $\mathrm{pH}$ values were within previously described values (Randall, 1977) for chronically catheterized fetuses.

Concentrations of progesterone and unconjugated oestrone in the fetal jugular vein did not change significantly during the 4-day period when dexamethasone was infused into the fetuses (Fig. 1). Oestrone concentrations in samples taken at Caesarian section from the umbilical vein of infused fetuses tended to be higher than those of non-infused fetuses, although small numbers precluded exact comparisons being made.

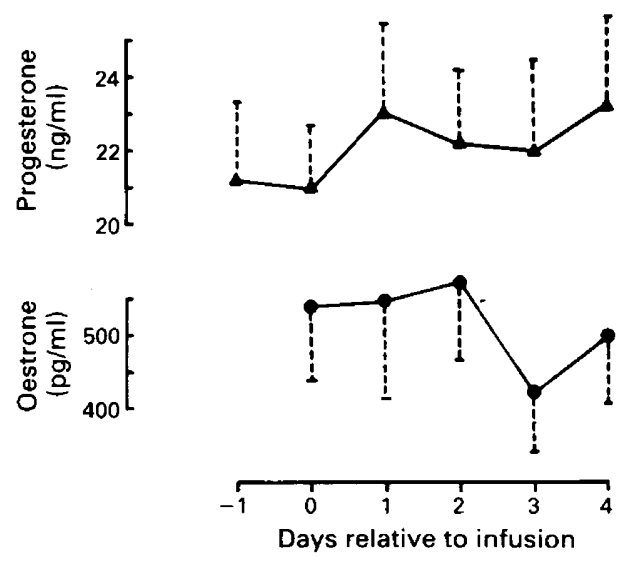

Fig. 1. Concentrations of progesterone \pm s.e.m. and unconjugated oestrone in 5 catheterized, hypophysectomized fetuses infused with dexamethasone for $96 \mathrm{~h}$.

In 3 of the 5 fetuses, from 2 sows, fetal oestrone concentrations were considerably higher in the samples taken on the first 2 days after surgery $(804-3476 \mathrm{pg} / \mathrm{ml})$ than on subsequent days. In addition, oestrone concentrations were higher in those samples taken at Caesarian section than in those taken through the catheter $1 \mathrm{~h}$ before anaesthesia.

\section{Discussion}

Although it has been known for some time that fetal progesterone concentrations are higher than maternal concentrations (Barnes et al., 1974; Silver et al., 1979; Hagen et al., 1983), there is relatively little information on the sources and function of the high fetal concentrations. Craig 
(1982) has demonstrated that the fetal placenta can produce progesterone in vitro and earlier suggestions that the placenta is an important source of progesterone in the fetus (Hagen et al., 1983; Nase, Hagen, Kavanaugh \& Griel, 1985) are supported in our study by the maintenance of high fetal concentrations and negative arterio-venous differences in umbilical vessels of fetuses in ovariectomized sows. However, there is also evidence that progesterone might be transferred from the maternal to the fetal circulation (Barnes et al., 1974), in which case the relative proportions arising from placental synthesis or maternal transfer remain to be determined.

In fetuses in which the pituitary was absent, fetal progesterone concentrations were higher than those in intact fetuses. Whether this reflected increased (or maintained) placental production, decreased metabolism or altered placental transfer could not be determined. Higher concentrations of unconjugated oestrogens were present in the intact fetuses: the use of progesterone as a substrate for their production (as discussed below) might explain, in part, differences between the two groups. However, other metabolic pathways for progesterone, which might also be affected by the pituitary, are present in the pig, e.g. $5 \alpha$ - and $5 \beta$-reduction (Craig, 1982). That the differences were due to variations in maternal concentrations seems unlikely since the intact and hypophysectomized fetuses in Exp. 2 shared a common maternal environment.

Concentrations of oestrogens increase during the last month of gestation in the fetal (Macdonald et al., 1979) and maternal (Robertson \& King, 1974) blood. The rapid decrease in oestrogens after parturition suggests that they are produced by the gravid uterus (Fèvre et al., 1968; Robertson \& King, 1979) and the negative arterio-venous difference in the uterine and umbilical circulations (Silver et al., 1979) indicates their placental origin. The high oestrogen content of placental tissue (Choong \& Raeside, 1974) and the demonstration that fetal placental tissue can convert androstenedione (Ainsworth \& Ryan, 1966) or pregnenolone (Craig, 1982) to oestrogens are additional evidence for the placental synthesis of oestrogens in the pig.

In the present study, a negative arterio-venous difference for unconjugated oestrone and oestradiol-17 $\beta$ was found in umbilical and uterine plasma, confirming earlier studies. Furthermore, it was found that the concentrations of these steroids were reduced in fetal and maternal plasma in the absence of a fetal pituitary. This extends the findings of Kendall et al. (1985) that lower oestradiol-17 $\beta$ concentrations were present in gilts carrying small numbers of hypophysectomized fetuses than in those carrying small numbers of intact fetuses. However, despite the lower concentrations, the negative arterio-venous difference persisted in the umbilical circulation for both steroids even when all fetuses in the litter were decapitated or hypophysectomized, suggesting that the placenta may produce 'base-line' quantities of oestrogens but that these are increased in a normally maturing fetus. Whether progesterone is a major substrate for oestrogen production before any increased $17 \alpha$-hydroxylase activity is not clear. The high oestrone concentrations in chronically-catheterized hypophysectomized fetuses in the days after surgery would suggest that other steroids may be converted to oestrogens.

Craig (1982) demonstrated that the fetal placenta has some ability to convert progesterone to oestrogens and that the 17a-hydroxylase activity increased between Days 106 and 114 of gestation, a period when fetal cortisol concentrations are increasing (Randall, 1983). The activation of this enzyme by cortisol is an essential step in the increased oestrogen production in sheep and goats (Anderson et al., 1975; Flint et al., 1978), and Craig (1982) suggested that a similar mechanism may be present in the pig. However, infusion of dexamethasone into catheterized hypophysectomized fetuses for $96 \mathrm{~h}$ did not cause significant alterations in either progesterone or oestrone in our study. The concentration infused was higher than that previously shown to suppress endogenous cortisol production in intact fetuses (Randall et al., 1984). It is possible that a longer period of infusion might be required to induce changes in oestrogen production. When ACTH or dexamethasone were infused into intact fetuses progesterone concentrations did fall, although only after about 6 days of infusion (G. C. B. Randall, J. Z. Kendall, B. K. Tsang \& M. A. M. Taverne, unpublished data), but oestrone concentrations did not increase markedly. Infusion of ACTH or dexamethasone into all fetuses in litters of reduced size (Randall et al., 1984) did not result in premature 
delivery and this may argue against a central role for corticosteroids as the trigger for parturition in the pig. However, Coggins \& First (1977) have also shown that maternally-administered dexamethasone did not induce parturition in gilts carrying decapitated fetuses and it is possible that the placentas of our hypophysectomized fetuses were unable to respond to dexamethasone in the absence of some other pituitary factor. The elevated oestrone concentrations in the plasma of 3 catheterized fetuses on the day after surgery are of interest in that they suggest that the placentas of these hypophysectomized fetuses were able to produce oestrone, presumably from some substrate other than progesterone since its levels were unaltered. These sows were ovariectomized and other possible substrates might therefore be steroids produced by the maternal adrenal gland after the stress of surgery.

In the current study we examined only unconjugated oestrogens and whether the differences are also present for total oestrogens is not known. Dwyer \& Robertson (1980) showed that endometrial oestrogen sulphatase activity increased whereas sulphotransferase decreased in late pregnancy. Whether the maturation of the fetus or its placenta can influence the relative activity of these enzymes in late gestation in the pig is not known. The role of oestrogens in the onset of parturition itself is still equivocal. Oestradiol-17 $\beta$ plays an important role in controlling prostaglandin production in sheep and goats but does not appear to play such a role in pigs (First \& Bosc, 1979). It is possible that it plays a less obligatory role in this species, e.g. by raising oxytocin receptor concentrations, or in lactation.

We thank Ms Soai Quyen Lu and Mr Y. Barbeau and Mr G. Raby for skilled technical assistance throughout this study; Mrs E. Meredith for careful attention to the animals; Dr L. M. Sanford and V. Trudeau for the LH assays; and Ms Joan Graham for preparation of the manuscript.

\section{References}

Ainsworth, L. \& Ryan, K.J. (1966) Steroid hormone transformations by endocrine organs from pregnant mammals. I. Oestrogen biosynthesis by mammalian placental preparations in vitro. Endocrinology 79, 875-883.

Anderson, A.B.M., Flint, A.P.F. \& Turnbull, A.C. (1975) Mechanism of action of corticosteroids in induction of ovine parturition: effect on placental steroid metabolism. J. Endocr. 66, 61-70.

Barnes, R.J., Comline, R.S. \& Silver, M. (1974) Foetal and maternal progesterone concentrations in the sow. J. Endocr. 62, 419-420.

Bosc, M., du Mesnil du Buisson, F. \& Locatelli, A. (1974) Mise en évidence d'un contrôle foetal de la parturition chez la truie. Interactions avec la fonction lutéale. C. r. hebd. Séanc. Acad. Sci., Paris, D 278, $1507-1510$.

Choong, C.H. \& Raeside, J.I. (1974) Chemical determination of oestrogen distribution in the foetus and placenta of the domestic pig. Acta endocr., Copenh. $77,171-185$.

Coggins, E.G. \& First, N.L. (1977) Effect of dexamethasone, methallibure and fetal decapitation on porcine gestation. J. Anim. Sci. 44, 1041-1049.

Craig, V.A. (1982) Placental steroid metabolism in late pregnancy. In Control of Pig Reproduction. pp. 405-418. Eds D. J. A. Cole \& G. R. Foxcroft. Butterworth Scientific, London.

Dwyer, R.J. \& Robertson, H.A. (1980) Oestrogen sulpha- tase and sulphotransferase activities in the endometrium of the sow and ewe during pregnancy. $J$. Reprod. Fert. 60, 187-191.

Fèvre, J., Léglise, P.-C. \& Rombauts, P. (1968) Du rôle de l'hypophyse et des ovares dans la biosynthese des oestrogènes aux cours de la gestation chez la truie. Annls Biol. anim. Biochim. Biophys. 8, 225-233.

First, N.L. \& Bosc, M.J. (1979) Proposed mechanisms controlling parturition and the induction of parturition in domestic animals. J. Anim. Sci. 48, 1407-1421.

Flint, A.P.F., Kingston, E.J., Robinson, J.S. \& Thorburn, G.D. (1978) Initiation of parturition in the goat: evidence for control by foetal glucocorticoid through activation of placental $\mathrm{C}_{21}$-steroid $17 \alpha$-hydroxylase. J. Endocr. 78, 367-378.

Hagen, D.R., Houtz, S.K., Griel, L.C. \& Kavanaugh, J.F. (1983) Concentrations of progesterone in arterial and venous plasma of fetal pigs and their dams in late gestation. Biol. Reprod. 29, 919-923.

Kendall, J.Z., Dziuk, P.J., Nelson, D.R. \& Thurmon, J.C. (1985) The effect of fetal hypophysectomy in gilts with small litters on plasma estradiol $17 \beta$ concentrations. Biol. Reprod. 32, Suppl. 1, 158, Abstr.

Macdonald, A.A., Elsaesser, F., Parvizi, N., Heilhecker, A., Smidt, D. \& Ellendorf,, F. (1979) Progesterone, oestradiol-17 $\beta$ and luteinizing hormone concentrations in the blood and amniotic fluid of chronically catheterized pig foetuses. J. Endocr. 80, 14P, Abstr.

Macdonald, A.A., Colenbrander, B., Elsasser, F. \& 
Heilhecker, A. (1980) Progesterone production by the pig fetus and the response to stimulation by adrenocorticotrophin. J. Endocr. 85, 34P, Abstr.

Murphy, B.E.P. (1971) 'Sephadex' column chromatography as an adjunct to competitive protein binding assays of steroids. Nature, New Biol. 232, 21-24.

Nase, B.R., Hagen, D.R., Kavanaugh, J.F. \& Griel, L.C. (1985) Effect of partial stepwise luteectomy in pregnant gilts on maternal and fetal concentrations of progesterone. Biol. Reprod. 33, 88-92.

Ponzilius, K.-H., Sanford, L.M., Phillips, G.D. \& Palmer, W.M. (1983) Blood hormone changes associated with puberty in the female pig. Can. J. Anim. Sci. 64, 177-181.

Randall, G.C.B. (1977) Daily changes in the blood of conscious pigs with catheters in foetal and uterine vessels during late gestation. J. Physiol., Lond. 270, 719-731.

Randall, G.C.B. (1983) Changes in the concentrations of corticosteroids in the blood of fetal pigs and their dams during late gestation and labor. Biol. Reprod. 29, 1077-1084.

Randall, G.C.B. (1986) Chronic implantation of catheters and other surgical techniques in fetal pigs. In Swine in Biomedical Research. Ed. M. E. Tumbleson. Plenum Publishing Corporation, New York (in press).
Randall, G.C.B., Kendall, J.Z., Tsang, B.K. \& Taverne, M.A.M. (1984) Role of the fetal adrenal in the timing of parturition in the pig. Proc. 10th Int. Congr. Anim. Reprod. \& A.I., Urbana 2, 108.

Randall, G.C.B., Taverne, M.A.M., Challis, J.R.G., Kendall J.Z. \& Tsang, B.K. (1986) Interrelationships between endocrine changes in peripheral and uterinevenous blood and uterine activity in the pig. Anim. Reprod. Sci. (in press).

Robertson, H.A. \& King, G.J. (1974) Plasma concentrations of progesterone, oestrone, oestradiol-17 $\beta$ and oestrone sulphate in the pig at implantation, during pregnancy and at parturition. J. Reprod. Fert. 40, 133-141.

Silver, M., Barnes, R.J., Comline, R.S., Fowden, A.L., Clover, L. \& Mitchell, M.D. (1979) Prostaglandins in the foetal pig and prepartum changes in mother and foetus. Anim. Reprod. Sci. 2, 305-322.

Stryker, J.L. \& Dziuk, P.J. (1975) Effects of fetal decapitation on fetal development, parturition and lactation in pigs. J. Anim. Sci. 40, 282-287.

Tsang, B.K., Armstrong, D.T. \& Whitfield, J.F. (1980) Steroid biosynthesis by isolated human ovarian follicular cells in vitro. J. clin. Endocr. Metab. 51, 1407-1411. 